\title{
Effect of Teachers' Knowledge Sharing Behavior on Students' Entrepreneurial Motivation in Social Media Environment
}

\author{
https://doi.org/10.3991/ijet.v17i02.28553 \\ Jiajing Li, Jian Qin $\left.{ }^{(}\right)$ \\ Hebei Jiaotong Vocational and Technical College, Shijiazhuang, China \\ qinjian@hejtxy.edu.cn
}

\begin{abstract}
The improvement of social media network and the enrichment of social media make the communication of modern people more convenient, break through the limitations of time and space, and meet the knowledge sharing between different groups. This study provides a model framework for teachers to promote students' entrepreneurial motivation through knowledge sharing. Through the questionnaire survey, the sample data of 111 teachers and students in 5 higher vocational colleges in Hangzhou, Zhejiang Province were collected. Through path analysis and mediation effect analysis, the four hypotheses of the model are analyzed and tested. The results show that the overall Cronbach coefficient of the questionnaire is 0.935 , which has high reliability. Kaiser - Meyer - Olkin (kmo) value is 0.884 , greater than 0.8. Research data information is very suitable for extracting information. Teachers' knowledge sharing can not play a direct and positive role in students' entrepreneurial motivation. Knowledge reciprocity between teachers and students can promote students' entrepreneurial motivation. The results of this study have important reference value for fully understanding how teachers' knowledge sharing behavior stimulates students' entrepreneurial motivation.
\end{abstract}

Keywords — social media, teachers' knowledge sharing behavior, student, entrepreneurial motivation, influence, mediating effect, path analysis

\section{Introduction}

The information age has promoted the rapid development and vigorous rise of social media, and the means of communication between people have become more diverse and fast. Social media has become a necessary part of Chinese residents' daily life and work. Social media has received good hardware support through good communication and information infrastructure, and has been widely developed with good software. Mobile users can form a huge social network through self-organization, deepen mutual communication, obtain mutual feedback, and generate specific social media content by sharing useful information. Such a huge social media constitutes an interactive and highly responsible knowledge ecosystem including a variety of knowledge. More people can be exposed to the corresponding knowledge through 
systematic management of knowledge sharing, and the diversity of knowledge sharing platforms comprehensively affects the links of knowledge acquisition, creation, regeneration, and sharing. Therefore, social media has exerted a profound influence on the interaction between teachers and students, so that they can share and learn knowledge anytime and anywhere. Various platforms of social media, including WeChat, short video app, today's headlines, and microblog, have made students become the main participants in network culture. Social media has become the main channel and favorite form for students to learn various knowledge and cultural exchanges.

In the era of artificial intelligence, teachers, as the main body of knowledge dissemination, are accustomed to the new means of social media. In addition to the traditional classroom teaching, teachers gradually like social media for knowledge dissemination. This type of social media environment has a certain effect on the dissemination of teachers' knowledge. Specifically, 5G technology has brought a smoother communication environment, making the knowledge learning between teachers and students break the limitation of time and space. With the gradual improvement of social media and the development of social networks, teachers can share knowledge through Weibo, WeChat, headlines, and other social means, and students use such social media to gain more self-learning space and stimulate endogenous learning motivation. Individual differences are found among teachers, and obvious differences are observed in teaching attitude, teaching methods, and teaching environment, thereby making the knowledge sharing of teachers in the social media environment more complex and diverse. From the perspective of economic man, teachers' knowledge is their own assets. Out of the uncertainty of protecting their own knowledge and career development, teachers usually do not take the initiative to share their accumulated knowledge, especially the knowledge with important value in entrepreneurship. However, the convenience and quickness of social media can promote teachers' richer knowledge sharing behavior to a certain extent. Previous studies mostly conducted knowledge sharing performance evaluation of different subjects in social media environment from the perspective of social network analysis and explored the factors affecting teachers' individual knowledge sharing behavior from the aspects of individual, personality, trust, organizational atmosphere, and leadership support. However, the existing research work lacks research on how teachers' knowledge sharing behavior affects students' entrepreneurial motivation. This study analyzes the relationship between teachers' knowledge sharing, mutual knowledge between teachers and students, and entrepreneurial motivation of students, and takes students' selfefficacy as an intermediary variable to analyze how it affects the relationship between mutual knowledge of teachers and students and entrepreneurial motivation of students, so as to construct a theoretical model of how teachers' knowledge sharing behavior motivation is transmitted to students' entrepreneurial motivation under social media environment. 


\section{Theoretical basis and research hypothesis}

\subsection{Theoretical basis}

Social exchange theory expounds the necessity of paying attention to the communication and interaction between the two sides of behavior. The two sides of communication pay more attention to the expectation of future benefits and the development of bilateral relations, which has become an important theoretical basis for the study and treatment of interpersonal communication and communication behavior based on psychology. In traditional economic theory, the basic premise assumption is economic man. Man will pursue the maximization of economic interests and think and judge the comparison between current costs and future benefits. When knowledge sharing occurs, knowledge, as a shared object, has measurable value factors and tradable attributes. Knowledge itself, especially entrepreneurial knowledge, is of great value because it comes from entrepreneurs' experience, and many entrepreneurial knowledge are difficult to measure by money. Therefore, if sharers want to share knowledge with others, then they will reduce the scarcity of their own knowledge. Therefore, they will not take knowledge sharing behavior, which is economic exchange. For teachers, their knowledge sharing behavior will cause knowledge diffusion, and teachers will no longer have the uniqueness of knowledge. Teachers take knowledge as their own, and teachers are willing to share their entrepreneurial knowledge with students. Social exchange theory provides a theoretical basis for solving this problem. Many studies believe that this theory provides a theoretical basis for the study of knowledge sharing behavior. Starting from this theory, we can find that teachers' behavior of knowledge sharing is essentially knowledge exchange and knowledge reciprocity between teachers and students. In this process, teachers share knowledge to obtain labor remuneration and is based on the essential requirements of teachers' profession. Teachers can enable students to acquire more skills, stimulate entrepreneurial motivation, promote students to be more successful, and enable them to obtain some form of reward expectation (such as evaluating professional titles, giving honors, performance rewards, etc.) in the future by sharing knowledge. The form of reward expectation should include students' knowledge sharing behavior to teachers after students grow up.

\subsection{Research hypothesis}

Knowledge sharing behavior involves knowledge sharers and knowledge receivers. In this study, teachers and students are a type of social interaction behavior. In this interaction process, the two sides exchange valuable knowledge and can access more options and relevant information [1]. Salopek, J. J research shows that knowledge sharing behavior has many types, where the most important form is process orientation [2]. Such a form of knowledge sharing can enable the knowledge subject to transfer knowledge to the object, let the other party understand knowledge, and master the knowledge content to the same extent as the subject. Marks, $\mathrm{P}$ believed that knowledge sharing is a process for others to obtain the knowledge of the subject of the sharer, so as to develop their ability and promote others to obtain effective behav- 
ior. Knowledge sharing behavior is related to learning and emphasizes the process state of knowledge flow [3]. Swart, J shared the knowledge owned by employees, which plays an important role for knowledge-intensive enterprises to obtain the maximum benefit from their intellectual capital and compete effectively in the market [4]. Knowledge sharing among employees must be promoted through human resource policies. The research results of Hew, K.F. show that collectivism and principality are the main motivations of knowledge sharing, and teachers can share knowledge in the practice community through computer networks [5]. Margrum-leys, J investigated the means in which teachers share and use teachers' knowledge. The results show that the application of Schulman model reveals a set of knowledge that originates from and is suitable for educational technology practice [6]. Asbari, M measured the influence of implicit and explicit knowledge sharing on teachers [7]. The results show that implicit and explicit knowledge sharing can obviously promote teachers' innovative ability. Chen, H.L. took 332 teachers in a virtual community of teachers' specialty in Taiwan Province as samples to explore the mechanism of individual knowledge sharing willingness and behavior change [8]. The results show that community trust affects the willingness of knowledge sharing and improves teachers' knowledge sharing behavior. Margerum-leys, J showed that teachers' increasing knowledge sharing in the teaching process can effectively strengthen students' understanding of the knowledge learned and believed that the interaction between students and teachers in the teaching environment is of great importance [9]. Darling Hammond, l considered that teachers' knowledge sharing plays an obvious role in promoting students' learning performance [10]. Therefore, teachers' knowledge sharing behavior can expose students to different perspectives and different viewpoints at present or in the future, integrate opinions, information and knowledge that have not been connected in the past from different angles, so as to generate new opinions, information, and knowledge, solve new problems, enhance creativity, and have a fundamental effect on entrepreneurial motivation. On the basis of the above analysis, hypothesis 1 is proposed.

H1: Teachers' knowledge sharing behavior has a positive effect on students' entrepreneurial motivation.

Social exchange theory proposes that the logic leading the success of exchange depends on reciprocal behavior. The two sides of knowledge exchange adopt the principle of reciprocity in the whole process of social exchange. This principle is the basic condition for the progress and development of social exchange. The definition of the principle of reciprocity is the basic criterion that two sides of the exchange must adopt in the process of exchange. This criterion can enable one side of the exchange to give some help to the other side, and the other side will consider returning and giving the former some valuable resources. Bartol, K. m believed that through this reciprocal behavior of mutual giving or exchange, individuals can connect with each other in the social emotional network, and individuals can maintain and strengthen this social emotional connection once this social emotional network is formed [11]. Sparrowe, R. $\mathrm{t}$ introduced a framework for understanding relationship quality on the basis of reciprocity. The results show that in enterprises, leaders help integrate some members into the internal life of the organization through the exchange process [12]. Uhl-Bien, $\mathrm{M}$ investigated the positive norms and negative norms of reciprocity in management 
work relationship [13]. The results show that the negative reciprocity group shows a lower level of performance and responsibility. Wu, J.B. confirmed the relationship between knowledge reciprocity types among employees and enterprise performance [14]. Barnes, M.E. thought that with the differences in the demographic structure of teachers and students, the opportunities of experiential learning in teacher education are becoming increasingly important [15]. The survey results show that communities and schools as important channels can enhance the understanding of the mutually beneficial relationship between teachers and students. Donahue, D.M. believed that the knowledge reciprocity between teachers and students is strongly influenced by teachers' willingness to share knowledge [16]. Youens, B analyzed the relationship between teachers and students by using video capture technology [17]. The results show that the interaction between teachers and students promotes the power of mutual learning in the whole partnership. Aukerman, M studied the interaction mechanism and mutual promotion between teachers and students in English teaching [18]. The results show that reciprocity is the key to promote two sides to jointly improve teaching and learning performance. Therefore, teachers' knowledge sharing behavior is a type of social exchange behavior between teachers and students in accordance with social exchange theory. In the process of this behavior, teachers and students actually exchange knowledge resources. In this social exchange behavior, reciprocal behavior is a type of selfless spirit, and teachers do not care what they will obtain if they give, but pay more attention to the interests of students. Teachers' behavior decision making ignores immediate rewards at present because teachers' knowledge sharing is determined by their professional characteristics rather than holding an expectation of receiving students' rewards in the future. Therefore, when teachers share knowledge about entrepreneurship with students, teachers will exchange their own knowledge resources by taking knowledge reciprocity, thereby promoting students to stimulate the endogenous motivation of entrepreneurship. On the basis of the above analysis, hypothesis 2 is proposed.

H2: Teachers" knowledge sharing behavior has a positive effect on teachers' and students' knowledge reciprocity.

Mutual knowledge between teachers and students can promote the knowledge appreciation of students, which is an increase in quantity and an improvement in quality. Each student can obtain different information and resources and produce different ideas and products because he has different internal and external resources. Knowledge reciprocity between teachers and students transfers teachers' resources about entrepreneurship to students, so that students' entrepreneurial motivation is improved. They can have more information and resources and generate more good ideas about entrepreneurship.

Bacanak, A thought that teachers' in-depth understanding of entrepreneurship can enable students to acquire entrepreneurial skills and have different understandings and practices [19]. Teachers who share common views on student-centered teaching methods and skills are effective in cultivating entrepreneurial skills. San martín, $\mathrm{P}$ believed that teachers' entrepreneurship education is considered to be the key means to improve students' entrepreneurial intention [20]. The comparative experiment shows that teachers' stories of some typical entrepreneurial models can improve stu- 
dents' entrepreneurial intention and improve students' attitudes and abilities. Fejes, A regarded that teachers should strengthen entrepreneurship education in teaching, and sharing entrepreneurship stories and knowledge through social media can effectively stimulate students' entrepreneurial motivation [21]. Huang, Y studied the effect of entrepreneurship education on teachers' and students' satisfaction in Chinese colleges and universities [22]. The results show that entrepreneurship education plays an important role in China's sustainable development, but teachers' lack of entrepreneurial experience and knowledge sharing lead to the unclear entrepreneurial motivation of students. Deveci, I investigated Turkish teachers' views and abilities on entrepreneurship [23]. The results show that teachers' knowledge sharing of entrepreneurship can promote students' entrepreneurial motivation. This study believes that mutual knowledge between teachers and students can enhance students' knowledge accumulation and understanding and enrich their skills in the field of entrepreneurship. Mutual knowledge between teachers and students can strengthen the interaction with all students, and a close relationship is found between students' entrepreneurial motivation and mutual knowledge between teachers and students. On the basis of the above analysis, hypothesis 3 is proposed.

H3: Knowledge reciprocity between teachers and students has a positive effect on students' entrepreneurial motivation.

The most important thing of self-efficacy is to control the degree of investment of students in using internal and external resources to complete the goal. When the internal motivation of students to complete the goal is stronger, they will actively focus their main energy and resources on the process of completing the goal, which will relatively reduce the investment in other aspects. Wilson, F studied the relationship between the entrepreneurial self-efficacy and entrepreneurial intention of adolescents and adult master of business administration [24]. The results show that these students' self-efficacy significantly affects their career intention. Gielnik, M. M. conducted a comparative analysis. The results show that the participants after entrepreneurship training have stronger entrepreneurial will, and the sense of self-efficacy can further stimulate entrepreneurial motivation [25] Pihie, Z.A.L. conducted a questionnaire survey on 1554 students. The results show that entrepreneurship is a career choice, and students' self-efficacy can obviously promote their entrepreneurial intention [26]. Laguna, M conducted a questionnaire survey on 332 unemployed people. The results show that a highly positive correlation is found between their intention to start a second business and their self-efficacy [27]. Culbertson, S.S. assessed the effect of goal orientation and self-efficacy on the prediction of entrepreneurship and management career development [28]. The results show that improving self-efficacy may affect entrepreneurship development. Using correlation analysis to study the influence of self-efficacy on social entrepreneurship in education. The results show that the selfefficacy dimension predicts the personal creativity and risk-taking characteristics of social entrepreneurs. The relationship between students' self-efficacy belief and entrepreneurial intention in the content and teaching methods of entrepreneurship courses. The results show that in the theory-oriented courses, higher self-efficacy is related to lower entrepreneurial intention, whereas in the practice-oriented courses, higher self-efficacy is related to higher entrepreneurial intention is related. Various colleges 
and vocational high schools in Turkey offer entrepreneurship and small business management courses. The results show that these entrepreneurship courses can stimulate students' entrepreneurial motivation, and self-efficacy plays a complete intermediary effect between them. The relationship between entrepreneurship intention and self-efficacy of students in some schools through a questionnaire. The results show that entrepreneurship education conducted by universities can significantly improve students' entrepreneurship intention, and self-efficacy plays a partial intermediary role in entrepreneurship intention and entrepreneurship education. The results show that the entrepreneurship education courses taught by students obviously improve the entrepreneurial self-efficacy, entrepreneurial attitude, and entrepreneurial mentality of students, and entrepreneurial attitude plays an obvious regulatory role in self-efficacy and entrepreneurship education. Conducted a questionnaire survey on 319 students. The results show that self-efficacy has a significant effect on students' entrepreneurial willingness. When teachers share knowledge about entrepreneurship, they will provide students with some up-to-date knowledge about entrepreneurship. When students receive the knowledge, students will ask questions or express their relevant views about the knowledge content provided by teachers. Students' sense of self-efficacy has a positive regulatory effect on the relationship between teacher-student knowledge reciprocity and students' entrepreneurial motivation. The stronger the students' sense of self-efficacy, the stronger the positive relationship between teacher-student knowledge reciprocity and students' entrepreneurial motivation, the lower the degree of students' sense of self-efficacy, and the weaker the positive relationship between teacher-student knowledge reciprocity and students. In this series of processes, teachers and students exchange their knowledge resources, the two sides can deepen their understanding of knowledge, obtain more knowledge, and transfer knowledge more effectively. On the basis of the above analysis, hypothesis 4 is proposed.

H4: Self-efficacy plays an intermediary role between knowledge reciprocity between teachers and students and entrepreneurial motivation of students.

Through a large number of literature review and theoretical summary, this study believes that teachers' knowledge sharing behavior, as a main source to stimulate students' entrepreneurial motivation, should play an important role, and social exchange theory believes that teachers' and students' knowledge reciprocity should play a transmission role between them. This study considers that students' entrepreneurial motivation itself belongs to psychological factors, therefore, students' self-efficacy should have a mediating effect between teachers' and students' knowledge reciprocity and students' entrepreneurial motivation. On the basis of the above analysis, the research and analysis route is proposed, as shown in Figure 1. 


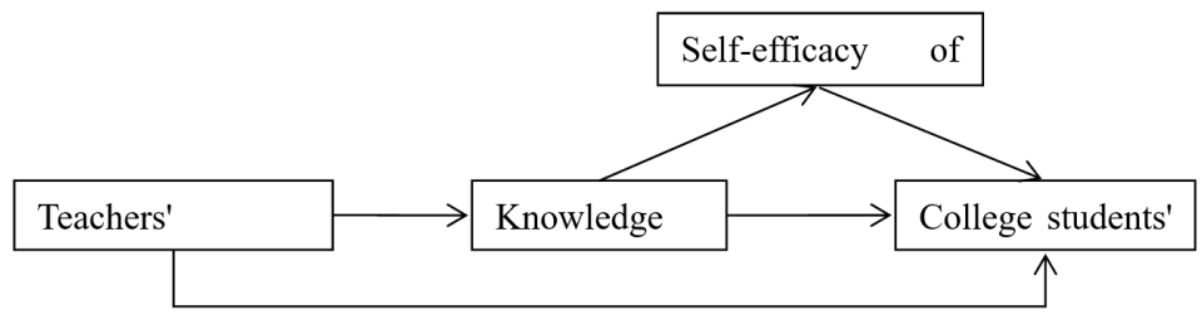

Fig. 1. Research and analysis path

\section{$3 \quad$ Research design and data acquisition}

\subsection{Questionnaire design}

This study takes vocational school teachers and students as the sample collection object, draws lessons from the relevant maturity scale, and designs a questionnaire combined with the actual situation of vocational school teachers and students. The questionnaire contains 20 questions, including 4 questions for statistical respondents' basic information, 4 questions for analyzing teachers' knowledge sharing behavior, 3 questions for mutual knowledge between teachers and students, 4 questions for students' entrepreneurial motivation, and 5 questions for self-efficacy. Before the formal distribution of questionnaire statistics, the author's research group conducted a smallscale test in the form of paper questionnaires, and the results were good. The statistical questions in this study are all from the questionnaires in the classic literature and have good potential reliability and validity. According to the suggestions of experts in the research group, the ambiguous Chinese sentences that easily affect the choice of the respondents are improved and modified.

\subsection{Data collection}

In this study, mobile online method is used to collect data. The research group distributes the designed questionnaire through the questionnaire star platform and generates the QR code of the questionnaire link, making it convenient for teachers and students in the university to answer the questionnaire in a fast and convenient manner. In China, ordinary higher education focuses on theoretical teaching, and higher vocational colleges conduct more training in technical skills. Under the background of China's vigorous development of small, medium-sized, and micro enterprises, higher vocational graduates have more extensive entrepreneurial space. Therefore, the author chose Hangzhou, Zhejiang Province as the destination city because Hangzhou is at the top of the list of Chinese students' entrepreneurship, and the overall entrepreneurial environment and entrepreneurial policies are better in China. Teachers and students are encouraged to take more active part in answering this questionnaire by directionally distributing the QR code of the questionnaire to the directors of the entrepreneurship education teaching and research section of five higher vocational colleges in 
Hangzhou. This process can ensure the authenticity and validity of the data answered by the questionnaire. A total of 198 questionnaires were distributed, and 162 were recovered. After the logical contradictions were eliminated, 111 valid questionnaires were obtained, with a recovery rate of $81.82 \%$ and an effective rate of $68.52 \%$.

\section{$4 \quad$ Data analysis and results}

\subsection{Reliability and validity test}

Reliability and validity test is the premise of questionnaire analysis. Cronbach's $\alpha$ coefficient is used for reliability test. The reliability test analysis of the four variables and the overall questionnaire is summarized in Table 1. The overall Cronbach coefficient of the questionnaire is 0.935 , and the Cronbach coefficients of the four variable factors are greater than 0.908 . The reliability of the questionnaire and sample data is high.

Table 1. Reliability test results

\begin{tabular}{|c|c|c|c|c|c|}
\hline Variable & $\begin{array}{c}\text { Issue item } \\
\text { number }\end{array}$ & \begin{tabular}{|c|} 
Total correlation \\
of correction \\
items (CITC)
\end{tabular} & $\begin{array}{c}\text { The alpha factor } \\
\text { of the item has } \\
\text { been deleted }\end{array}$ & $\begin{array}{c}\text { Cronbach } \alpha \\
\text { coefficient }\end{array}$ & $\begin{array}{l}\text { Cronbach } \alpha \\
\text { coefficient }\end{array}$ \\
\hline \multirow{4}{*}{$\begin{array}{l}\text { Teachers' knowledge } \\
\text { sharing behavior } \\
\text { A }\end{array}$} & A1 & 0.711 & 0.916 & \multirow{4}{*}{0.910} & \multirow{16}{*}{0.935} \\
\hline & A2 & 0.878 & 0.860 & & \\
\hline & $\mathrm{A} 3$ & 0.773 & 0.891 & & \\
\hline & A4 & 0.843 & 0.866 & & \\
\hline \multirow{3}{*}{$\begin{array}{l}\text { Knowledge reciprocity } \\
\text { between teachers and } \\
\text { students } \\
\text { B }\end{array}$} & B1 & 0.866 & 0.859 & \multirow{3}{*}{0.919} & \\
\hline & B2 & 0.864 & 0.861 & & \\
\hline & B3 & 0.789 & 0.923 & & \\
\hline \multirow{4}{*}{$\begin{array}{l}\text { Students' entrepreneur- } \\
\text { ial motivation } \\
\text { C }\end{array}$} & $\mathrm{C} 1$ & 0.819 & 0.873 & \multirow{4}{*}{0.908} & \\
\hline & $\mathrm{C} 2$ & 0.815 & 0.875 & & \\
\hline & $\mathrm{C} 3$ & 0.894 & 0.844 & & \\
\hline & $\mathrm{C} 4$ & 0.661 & 0.930 & & \\
\hline \multirow{5}{*}{$\begin{array}{l}\text { Self efficacy } \\
\text { D }\end{array}$} & D1 & 0.831 & 0.930 & \multirow{5}{*}{0.942} & \\
\hline & $\mathrm{D} 2$ & 0.884 & 0.921 & & \\
\hline & D3 & 0.889 & 0.92 & & \\
\hline & $\mathrm{D} 4$ & 0.877 & 0.922 & & \\
\hline & D5 & 0.743 & 0.948 & & \\
\hline
\end{tabular}

Combined with the evaluation criteria of various indicators and in-depth analysis of the relevant data in Table 2, ave (mean variance extraction) and $\mathrm{Cr}$ (combined reliability) are used for aggregation validity (convergent validity) analysis. Aggregation validity is high if ave is greater than 0.5 and $\mathrm{Cr}$ value is greater than 0.7 . 
Paper —Effect of Teachers' Knowledge Sharing Behavior on Students' Entrepreneurial Motivation in...

Table 2. Model ave and $\mathrm{Cr}$ index results

\begin{tabular}{|l|c|c|}
\hline \multicolumn{1}{|c|}{ Factor } & Mean variance extraction ave value & Combined reliability CR value \\
\hline A & 0.743 & 0.920 \\
\hline B & 0.684 & 0.866 \\
\hline C & 0.615 & 0.862 \\
\hline D & 0.740 & 0.934 \\
\hline
\end{tabular}

As shown in Table 3, KMO and Bartlett tests are used for validity verification. From the above table, the KMO value is 0.884 , which is greater than 0.8 . The research data information is extremely suitable for extracting information.

Table 3. Inspection of Kaiser-Meyer-Olkin (KMO) and Bartlett

\begin{tabular}{|l|c|c|}
\hline \multicolumn{2}{|c|}{ Kmo value } & 0.884 \\
\hline \multirow{3}{*}{ Bartlett sphericity test } & Approximate chi square & 1751.160 \\
\cline { 2 - 3 } & df & 120 \\
\cline { 2 - 3 } & p value & 0.000 \\
\hline
\end{tabular}

As shown in Table 4, confirmatory factor analysis can be used for discriminant validity research. In Table 3, the diagonal is the square root of ave, and the other values are the correlation coefficients. The square root value of ave can represent the aggregation of factors, and the correlation coefficient represents the correlation relationship. Discriminant validity is observed if the aggregation of factors is strong and the square root of a factor ave is greater than the absolute value of the correlation coefficient between the factor and other factors. All factors show such a conclusion, showing that this study has good discriminant validity. In conclusion, the dimensions of the scale designed in this study have good reliability and convergent validity.

Table 4. Discriminant validity: Pearson correlation and square root of ave

\begin{tabular}{|l|c|c|c|c|}
\hline & A & B & C & D \\
\hline A & 0.862 & - & - & - \\
\hline B & 0.411 & 0.827 & - & - \\
\hline C & 0.329 & 0.773 & 0.784 & - \\
\hline D & 0.512 & 0.715 & 0.635 & 0.861 \\
\hline
\end{tabular}

\subsection{Hypothesis verification}

Path analysis is used to verify Figure 1, and the path analysis results are shown in Table 5. 
Paper —Effect of Teachers' Knowledge Sharing Behavior on Students' Entrepreneurial Motivation in...

Table 5. Summary of the regression coefficient of model

\begin{tabular}{|c|c|c|c|c|c|c|c|}
\hline $\mathbf{X}$ & $\rightarrow$ & $\mathbf{Y}$ & Non-standardized path coefficient & $\mathbf{S E}$ & $\mathbf{Z}$ (CR value) & $\mathbf{p}$ & $\begin{array}{c}\text { Standardized path } \\
\text { coefficient }\end{array}$ \\
\hline $\mathrm{B}$ & $\rightarrow$ & $\mathrm{C}$ & 0.839 & 0.072 & 11.632 & 0.000 & 0.768 \\
\hline $\mathrm{A}$ & $\rightarrow$ & $\mathrm{C}$ & 0.013 & 0.065 & 0.195 & 0.845 & 0.013 \\
\hline $\mathrm{A}$ & $\rightarrow$ & $\mathrm{B}$ & 0.371 & 0.078 & 4.754 & 0.000 & 0.411 \\
\hline
\end{tabular}

The following conditions are shown in Table 5.

Hypothesis H1 is not tenable. Specifically, teachers' knowledge sharing behavior has a positive effect on students' entrepreneurial motivation. When a affects $C$, this path does not show significance $(\mathrm{z}=0.195, \mathrm{p}=0.845>0.05)$, pp. otherwise, a does not affect $C$. Theoretically, teachers' knowledge sharing behavior should promote students' entrepreneurial motivation, but the survey data in this study do not support this conclusion. The main possible reason is that teachers directly share knowledge. If environmental factors and personal factors are ignored, they cannot directly stimulate students' entrepreneurial motivation.

Hypothesis H2 holds. Teachers' knowledge sharing behavior has a positive effect on the mutual benefit of teachers and students. When A affects B, the normalized path coefficient value is $0.411>0$, and this path is significant at 0.01 level $(\mathrm{z}=4.754, \mathrm{p}=$ $0.000<0.01)$, pp. indicating that A has a significant positive influence on B. Teachers' knowledge sharing behavior has a positive effect on teachers' and students' knowledge reciprocity. The survey data show that a significant positive correlation is found between teachers' knowledge sharing behavior and teachers' and students' knowledge reciprocity. This finding preliminarily supports that teachers' knowledge sharing behavior has a positive effect on teachers' and students' knowledge reciprocity.

Hypothesis H3 holds. The knowledge reciprocity between teachers and students has a positive effect on students' entrepreneurial motivation. When B affects $\mathrm{C}$, the normalized path coefficient value is $0.768>0$, and this path is significant at 0.01 level $(\mathrm{z}=11.632, \mathrm{p}=0.000<0.01), \mathrm{pp}$. indicating that $\mathrm{B}$ has a significant positive influence on C. Entrepreneurial motivation for students should be studied in school every day, and teachers process and share knowledge into knowledge reciprocity between teachers and students. Thus, students can participate in the whole process of teachers' entrepreneurial knowledge sharing, which can meet the internal motivation of students' entrepreneurship and effectively promote their entrepreneurial performance.

Intermediary analysis is used to test the hypothesis of H4: Self-efficacy plays an intermediary role between knowledge reciprocity between teachers and students and entrepreneurial motivation of students.

As shown in Table 6, the intermediary effect analysis involves three models, which are as follows: $\mathrm{C}=0.200+0.844 * \mathrm{~B} ; \mathrm{D}=1.059+0.774 * \mathrm{~B} ; \mathrm{C}=$ $0.019+0.712 * \mathrm{~B}+0.171 * \mathrm{D}$. 
Paper —Effect of Teachers' Knowledge Sharing Behavior on Students' Entrepreneurial Motivation in...

Table 6. Intermediary effect model test

\begin{tabular}{|l|c|c|c|}
\hline & C & D & C \\
\hline Constant & $0.200(0.892)$ & $1.059^{* *}(4.333)$ & $0.019(0.079)$ \\
\hline B & $0.844^{* *}(12.730)$ & $0.774^{* *}(10.671)$ & $0.712^{* *}(7.610)$ \\
\hline D & & & $0.171(1.971)$ \\
\hline Sample size & 111 & 111 & 111 \\
\hline $\mathrm{R}^{2}$ & 0.598 & 0.511 & 0.612 \\
\hline Adjust $\mathrm{R}^{2}$ & 0.594 & 0.506 & 0.605 \\
\hline F value & $\mathrm{F}(1,109)=162.054, \mathrm{p}=0.000$ & $\mathrm{~F}(1,109)=113.879, \mathrm{p}=0.000$ & $\mathrm{~F}(2,108)=85.115, \mathrm{p}=0.000$ \\
\hline
\end{tabular}

${ }^{*} \mathrm{P}<0.05{ }^{* *} \mathrm{P}<0.01$ the value of $\mathrm{T}$ in brackets

Suppose H4 holds. As shown in Table 7, self-efficacy plays a partial intermediary role between teachers' and students' knowledge reciprocity and students' entrepreneurial motivation. The main reason may be that in addition to the subjective factors of students, some environmental factors (such as entrepreneurship policy, financial support, etc.) should be considered. The hypothesis results show that students with strong responsibility motivation and spiritual motivation will be more confident in their entrepreneurial ability and optimistic about their self cognition. The stronger the sense of self-efficacy of students, the more it can make the knowledge of teachers and students mutually beneficial and enhance the potential space of students' entrepreneurial motivation. Students' entrepreneurial motivation is not simply formed because it belongs to the category of psychology. It can only make students conduct the inner psychological level of entrepreneurial behavior through their own and environmental factors, which is a step-by-step in-depth process. They can enhance their entrepreneurial self-efficacy, be confident in themselves, further deepen their psychological level, and improve their willingness to participate in entrepreneurship by stimulating their own enthusiasm for starting a business and recognizing their innovative motivation. Students have entrepreneurial ideas on the basis of spiritual motivation and responsibility motivation. With the deepening of their entrepreneurial motivation, their sense of self-efficacy gradually accumulates and becomes stronger. At the beginning of teachers' knowledge sharing, students' entrepreneurial motivation only stays at the theoretical level, and entrepreneurial motivation is weak. With the gradual participation of self-efficacy in the formation of entrepreneurial motivation, students' entrepreneurial motivation improves obviously.

Table 7. Mediation test results

\begin{tabular}{|c|c|c|c|c|c|c|c|c|c|c|}
\hline Item & $\begin{array}{c}\mathrm{C} \text { total } \\
\text { effect }\end{array}$ & $\mathbf{a}$ & b & $\begin{array}{c}A^{*} b \text { media- } \\
\text { tion effect } \\
\text { value }\end{array}$ & $\begin{array}{c}\text { A"b }^{*} \mathbf{b} \\
\text { (Boot } \\
\text { SE) }\end{array}$ & $\begin{array}{l}A^{*} b(z \\
\text { value })\end{array}$ & $\begin{array}{l}A^{*} b(p \\
\text { value })\end{array}$ & $\begin{array}{c}A^{*} b(95 \% \\
\text { Boot CI) }\end{array}$ & $\begin{array}{c}C^{\prime} \\
\text { direct } \\
\text { effect }\end{array}$ & Test results \\
\hline $\begin{array}{l}\mathrm{B}=>\mathrm{D} \\
\Rightarrow>\mathrm{C}\end{array}$ & $0.844^{* *}$ & $0.774^{* *}$ & 0.171 & 0.132 & 0.005 & 24.976 & 0 & $\begin{array}{c}0.022 \sim \\
0.241\end{array}$ & $0.712^{*}$ & $\begin{array}{l}\text { Partial inter- } \\
\text { mediary }\end{array}$ \\
\hline
\end{tabular}




\section{Conclusion}

In recent years, entrepreneurship education has been incorporated into the daily curriculum of students in China, and teachers' sharing of entrepreneurship knowledge plays an important role. In the social media environment, an efficient and fast social media platform can further realize the aggregation, personalized presentation, and effective interaction of entrepreneurial knowledge resources. Universities promote teachers' participation in entrepreneurial knowledge sharing through various mechanisms and formulate incentive schemes for teachers' knowledge sharing. This process can comprehensively improve the whole process of teachers' participation in entrepreneurial knowledge sharing. On the basis of social exchange theory, this study constructs a transmission path model of teachers' knowledge sharing affecting students' entrepreneurial motivation in the social media environment from four aspects: teachers' knowledge sharing, teachers' knowledge reciprocity, students' self-efficacy, and students' entrepreneurial motivation. A total of 111 samples of teachers and students from 5 higher vocational schools in Hangzhou, Zhejiang Province were collected through questionnaire survey, and four hypotheses of the model were analyzed and tested through path analysis and intermediary effect analysis. The results show that teachers' knowledge sharing cannot directly play a positive role in students' entrepreneurial motivation. Knowledge reciprocity between teachers and students can promote students' entrepreneurial motivation. Self-efficacy plays a partial mediating role between knowledge reciprocity between teachers and students and entrepreneurial motivation of students. In addition to self-efficacy, environmental factors (entrepreneurial policy, financial support) should be further considered as the intermediary variables between mutual knowledge of teachers and students to promote students' entrepreneurial motivation. Environmental factors can be included in the analysis of intermediary effect in the future.

\section{Acknowledgements}

The study was supported by the Human resources and social security of Hebei Province in 2021, Topic name: Research on the cultivation of vocational core literacy of higher vocational college students; Project number: JRSHZ-2021-02111.

\section{$7 \quad$ References}

[1] Blau, P. M. Exchange and power in social life. Routledge, 2017.

[2] Salopek, J. J., \& Dixon, N. M. Common knowledge: How companies thrive by sharing what they know. Training \& Development, 2000, vol. 54(4), pp. 63-64.

[3] Marks, P., Polak, P., McCoy, S., \& Galletta, D. Sharing knowledge. Communications of the ACM, 2008, vol. 51(2), pp. 60-65. https://doi.org/10.1145/1314215.1314226

[4] Swart, J., \& Kinnie, N. Sharing knowledge in knowledge-intensive firms. Human resource management journal, 2003, vol. 13(2), pp. 60-75. https://doi.org/10.1111/j.1748-8583. $\underline{2003 . t b 00091 . x}$ 
Paper —Effect of Teachers' Knowledge Sharing Behavior on Students' Entrepreneurial Motivation in...

[5] Hew, K. F., \& Hara, N. Empirical study of motivators and barriers of teacher online knowledge sharing. Educational technology research and development, 2007, vol. 55(6), pp. 573-595. https://doi.org/10.1007/s11423-007-9049-2

[6] Margerum-Leys, J., \& Marx, R. W. The nature and sharing of teacher knowledge of technology in a student teacher/mentor teacher pair. Journal of Teacher Education, 2004, vol. 55(5), pp. 421-437. https://doi.org/10.1177/0022487104269858

[7] Asbari, M., Wijayanti, LM, Hyun, CC, Purwanto, A., \& Santoso, PB. Effect of Tacit and explicit knowledge sharing on teacher innovation capability. Dinamika Pendidikan, 2019, vol. 14(2), pp. 227 -243. https://doi.org/10.15294/dp.v14i2.22732

[8] Chen, HL, Fan, HL, \& Tsai, CC. The role of community trust and altruism in knowledge sharing: An investigation of a virtual community of teacher professionals. Journal of Educational Technology \& Society, 2014, vol. 17(3), pp. 168-179.

[9] Margerum-Leys, J., \& Marx, R. W. Teacher knowledge of educational technology: A case study of student/mentor teacher pairs. Journal of Educational Computing Research, 2002, vol. 26(4), pp. 427-462. https://doi.org/10.2190/jxbr-2g0g-1e4t-7t4m

[10] Darling-Hammond, L. Teacher learning that supports student learning. Teaching for Intelligence, 2008, vol. 2(1), pp. 91-100.

[11] Bartol, K. M., \& Srivastava, A. Encouraging Knowledge Sharing: The Role of Organizational Reward Systems. Journal of Leadership \& Organizational Studies, 2002, vol. 9(1), pp. 64-76. https://doi.org/10.1177/107179190200900105

[12] Sparrowe, R. T., \& Liden, R. C. Process and structure in leader-member exchange. Academy of management Review, 1997, vol. 22(2), pp. 522-552. https://doi.org/10.5465/ amr.1997.9707154068

[13] Uhl-Bien, M., \& Maslyn, J. M. Reciprocity in Manager-Subordinate Relationships: Components, Configurations, and Outcomes. Journal of Management, 2003, vol. 29(4), pp. 511-532. https://doi.org/10.1016/s0149-2063_03_00023-0

[14] Wu, JB, Hom, PW, Tetrick, LE, Shore, LM, Jia, L., Li, C., \& Song, LJ. The norm of reciprocity: Scale development and validation in the Chinese context. Management and Organization Review, 2006, vol. 2(3), pp. 377-402. https://doi.org/10.1111/j.1740-8784. 2006.00047.x

[15] Barnes, M. E. Encouraging interaction and striving for reciprocity: The challenges of community-engaged projects in teacher education. Teaching and Teacher Education, 2017, 68, pp. 220-231. https://doi.org/10.1016/j.tate.2017.09.004

[16] Donahue, D. M., Bowyer, J., \& Rosenberg, D. Learning with and learning from: Reciprocity in service learning in teacher education. Equity \&Excellence in Education, 2003, vol. 36(1), pp. 15-27. https://doi.org/10.1080/10665680303498

[17] Youens, B., Smethem, L., \& Sullivan, S. Promoting collaborative practice and reciprocity in initial teacher education: realising a'dialogic space'through video capture analysis. Journal of Education for Teaching, 2014, vol. 40(2), pp. 101-113. https://doi.org/10.1080/ $\underline{02607476.2013 .871163}$

[18] Aukerman, M., Johnson, EM, \& Chambers Schuldt, L. Reciprocity of student and teacher discourse practices in monologically and dialogically organized text discussion. Journal of Language and Literacy Education, 2017, vol. 13(2), pp. 1- 52.

[19] Bacanak, A. Teachers' Views about Science and Technology Lesson Effects on the Development of Students' Entrepreneurship Skills. Educational Sciences: Theory and Practice, 2013, vol. 13(1), pp. 622-629.

[20] San-Martín, P., Fernández-Laviada, A., Pérez, A., \& Palazuelos, E. The teacher of entrepreneurship as a role model: Students' and teachers' perceptions. The International Journal of Management Education, 2019, pp. 100358. https://doi.org/10.1016/j.ijme.2019.100358 
Paper —Effect of Teachers' Knowledge Sharing Behavior on Students' Entrepreneurial Motivation in...

[21] Fejes, A., Nylund, M., \& Wallin, J. How do teachers interpret and transform entrepreneurship education? Journal of Curriculum Studies, 2019, vol. 51(4), pp. 554-566. https:// doi.org/10.1080/00220272.2018.1488998

[22] Huang, Y., Liu, L., \& An, L. Are the Teachers and Students Satisfied: Sustainable Development Mode of Entrepreneurship Education in Chinese Universities? Frontiers in Psychology, 2020, 11, vol. 1738. https://doi.org/10.3389/fpsyg.2020.01738

[23] Deveci, I. Perceptions and competence of Turkish preservice science teachers with regard to entrepreneurship. Australian Journal of Teacher Education, 2016, vol. 41(5), pp. 153170. https://doi.org/10.14221/ajte.2016v41n5.10

[24] Wilson, F., Kickul, J., \& Marlino, D. Gender, entrepreneurial self-efficacy, and entrepreneurial career intentions: implications for entrepreneurship education. Entrepreneurship Theory and Practice, 2010, vol. 31(3), pp. 387-406. https://doi.org/10.1111/j.15406520.2007.00179.x

[25] Gielnik, M. M., Bledow, R., \& Stark, M. S. A dynamic account of self-efficacy in entrepreneurship. Journal of Applied Psychology, 2020, vol. 105(5), pp. 487. https://doi.org/ 10.1037/ap10000451

[26] Pihie, Z. A. L., \& Akmaliah, Z. Entrepreneurship as a career choice: An analysis of entrepreneurial self-efficacy and intention of university students. European journal of social sciences, 2009, vol. 9(2), pp. 338-349.

[27] Laguna, M. Self-efficacy, self-esteem, and entrepreneurship among the unemployed. Journal of Applied Social Psychology, 2013, vol. 43(2), pp. 253-262. https://doi.org/10.1111/ j.1559-1816.2012.00994.x

[28] Culbertson, S. S., Smith, M. R., \& Leiva, P. I. Enhancing entrepreneurship: The role of goal, 2011.

\section{Authors}

Jiajing Li is a Lecturer in Hebei Jiaotong Vocational and Technical College, Shijiazhuang, 050035, China.

Jian Qin is an associate professor in Hebei Jiaotong Vocational and Technical College, Shijiazhuang, 050035, China.

Article submitted 2021-10-15. Resubmitted 2021-12-02. Final acceptance 2021-12-04. Final version published as submitted by the authors. 